Historic, Archive Document

Do not assume content reflects current scientific knowledge, policies, or practices. 



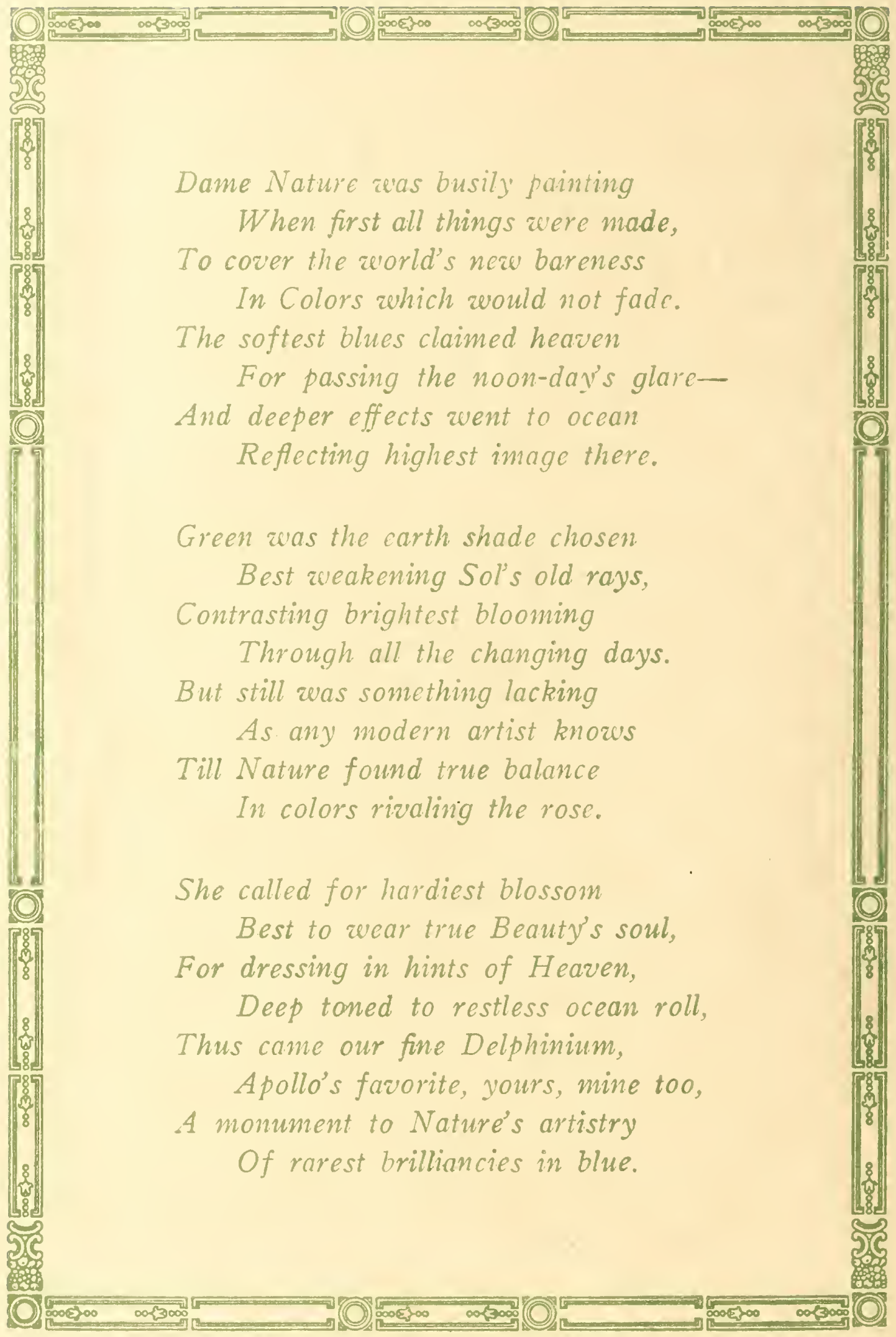

(Comflete contents copyrighted) 


\section{The Barclay Delphiniums}

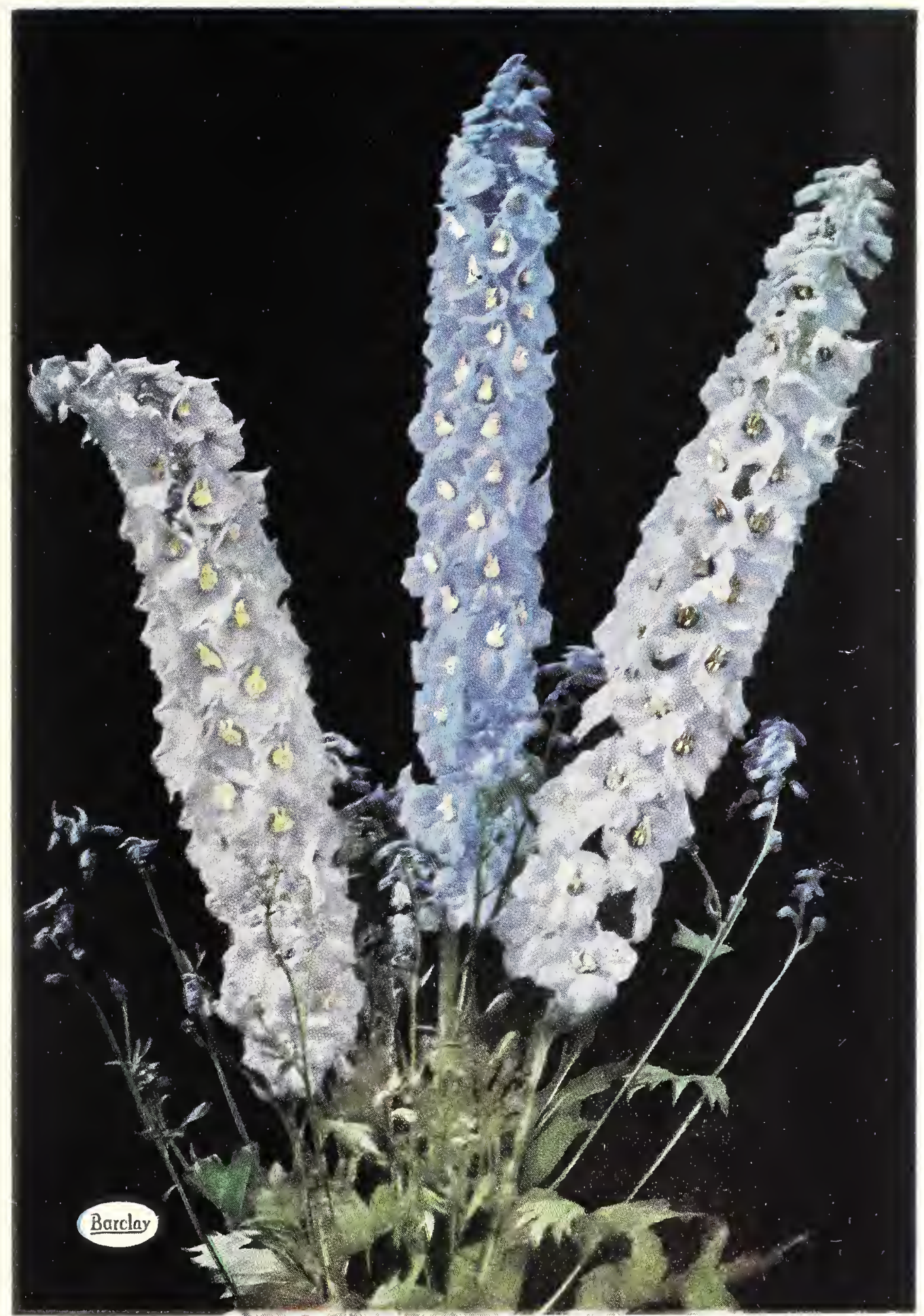

"The super-select in Modern Delphiniums"

James Forbes Barclay

Delphinium Specialist

287 Eastchester Road New Rochelle, N.Y. 


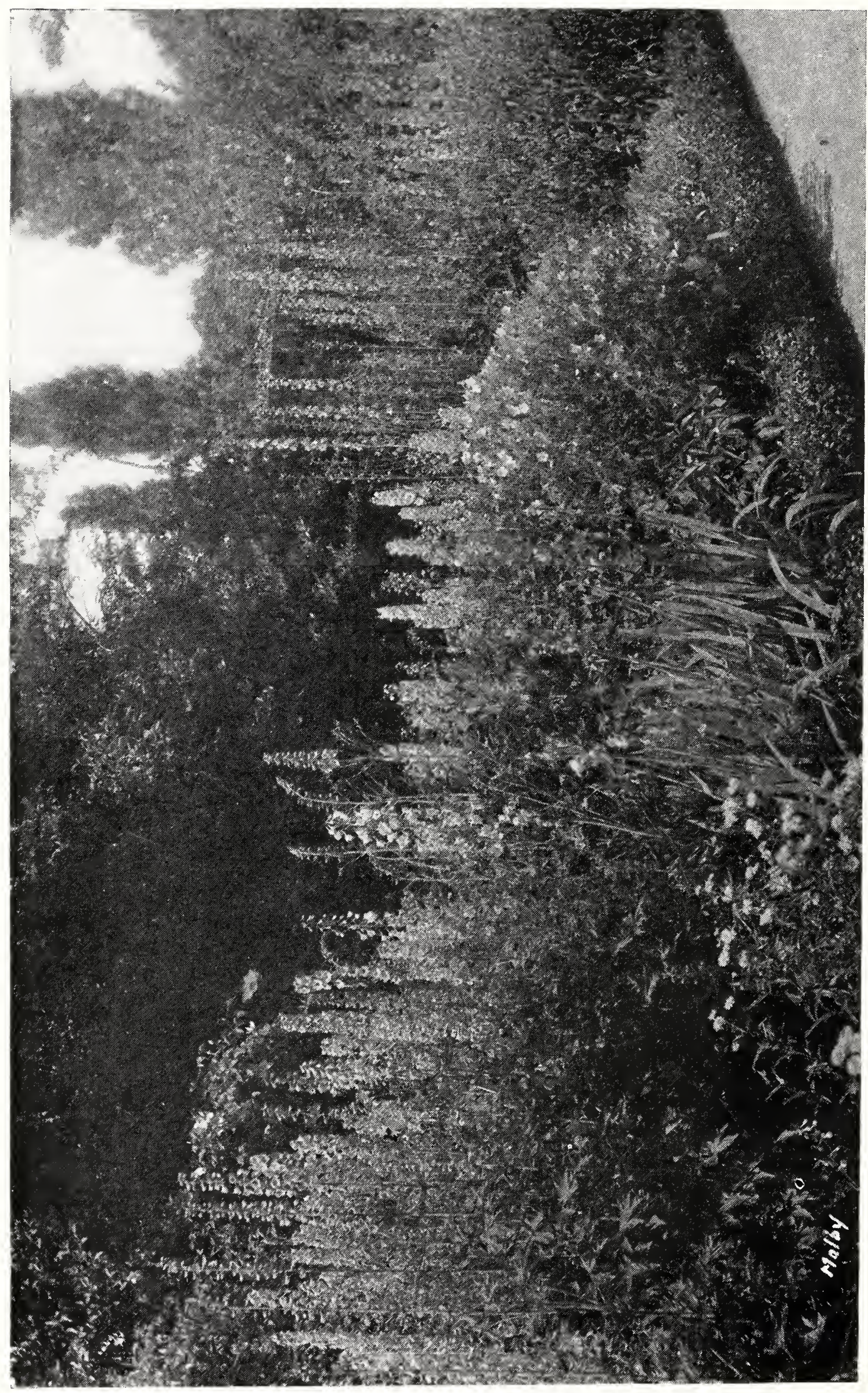

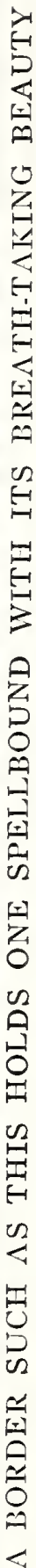




\section{F O R E W O R D}

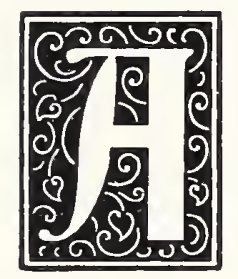

FEW years ago, after a lifetime devoted to Horticulture, both on private estates and growing for the commercial cut flower market, I became especially interested in Delphiniums; in fact, I may say it was compulsory rather than voluntary, for their superb qualities seemed to appeal to me and say-"Please do something to put us where we belong-among the foremost of Hardy Garden Flowers."

I conceived the idea of testing out all the finest Hybrid strains I could find, both here and in Europe, grown by the leading specialists in both countries. Now, as I have always believed that anything half done means nothing accomplished, I decided to obtain and test every stock I could find, and started with the six leading American and four best English strains-over 150 named varieties in all, but as seed from named sorts does not come true to the parent in type or color, many have been discarded as they did not come up to the "Barclay" standard of perfection.

The work has been very interesting, and, on the whole, satisfactory, and I now have a wonderfully fine lot of superb Hybrids.

Mr. Weston, Horticultural Editor of the Florists' Exchange, said of them after he had seen them the latter part of September, 1926:

"It is no exaggeration to say that this batch would require some beating. Domestic raisers will, indeed, have to go some to surpass it, even to keep up with it, from what we have seen, they have not done so."

"The great towering spikes from these one-year plants literally dwarfed most of the finest that could be found in the various other strains, although we were assured that the best have been cut or the plants sold outright."

To give an idea of the care and expert knowledge required in keeping my strain up to A-1 quality, my critical judgment demands such relentless "rogueing" that, out of 200,000 seedlings, blooming for the first time, only 25,000 were retained. Following up the advantage gained by my 1925 and 1926 experiences, I have selected only the choicest offerings of the most renowned specialists, and for my 1927 trials, I have sown some 600,000 seeds of the finest named varieties, including many novelties not yet offered.

All the shades known and now in commerce, are represented in "Barclay Hybrids" from the faintest and delicate mauves and lavenders, covering all the intermediate shades, down to the deep blues and violet, double flowered and single. This past summer I have noticed and marked some of a rosy red color that I have never seen before, also some very fine cream colored types, one a very beautiful double, and several of what are known as "Ranunculus" flowered type.

\section{Barclay}


Some beautiful lavenders and true blues in huge spikes are others that I am watching with interest.

The famous "Wrexham" type, the undoubted leader of this great family, is well represented in my valuable acreage, which harbors 85,000 seedlings, 25,000 of which are the improved "Advancement" type; this variety is acknowledged the world over to be the most wonderful Delphinium in commerce. This is the largest planting of Wrexham Delphiniums in America, and when in bloom from July on through the summer of this year, will be well worth coming many miles to see.

During this period I shall have many other choice types, blooming for the first time, and I would respectfully suggest to those who desire something extra choice for their gardens, that they pay a visit to my trial grounds, when plants may be selected, marked and shipped then or in the fall.

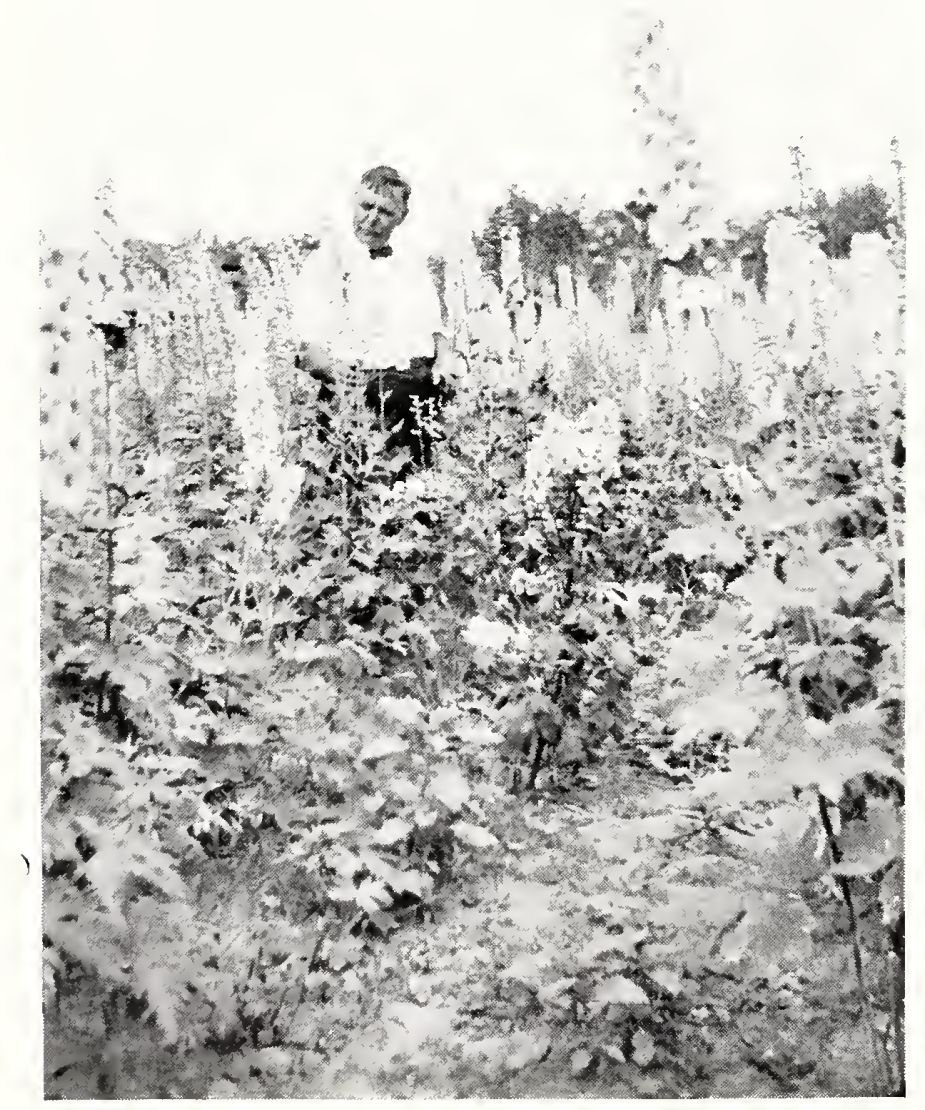

"THE BARCLAYS"

As practically all the named types are represented in form and color, in my unnamed seedlings, I can duplicate any chosen color or type, selected from the named sorts. The descriptions of these named varieties are given further on in this booklet, for the guidance of those who cannot visit my grounds, and as these field selections are personally done by myself-one is practically assured of getting the color and type ordered.

I further guarantee to replace any plant received that is not exactly as ordered.

This practice of selecting types from my seedlings to match the named sorts is made necessary by the Federial Horticultural Board Quarantine which prohibits the importation of plants except under special permit, but the packing methods, inspection delays, etc., are so risky and detrimental to the plants that I have decided 
not to import named sorts, except for my trial beds.

Barclay, Super-selected $\mathrm{H}$ y brids stand supreme, both for exhibition and decorative work in the garden.

Growing such a vast quantity of plants, varying in type, colors, form, etc., it is impossible to fix a straight price for the complete range.

New colors and forms are constantly appearing in the rows, in limited quantities, of course, while other forms, also good, are more plentiful, but all are far above the average standard to be found in American Nurseries.

Selections must, therefore, be left to my judgment, guided, of course, by the preferred shades and types suggested by the customer.

These and accompanying photos were all taken at Test Gardens here during summer of 1926 . Note the noble spike on Page 9, taken early in September. It is one of the seedling plants shown below, photo of which was taken July 5 .

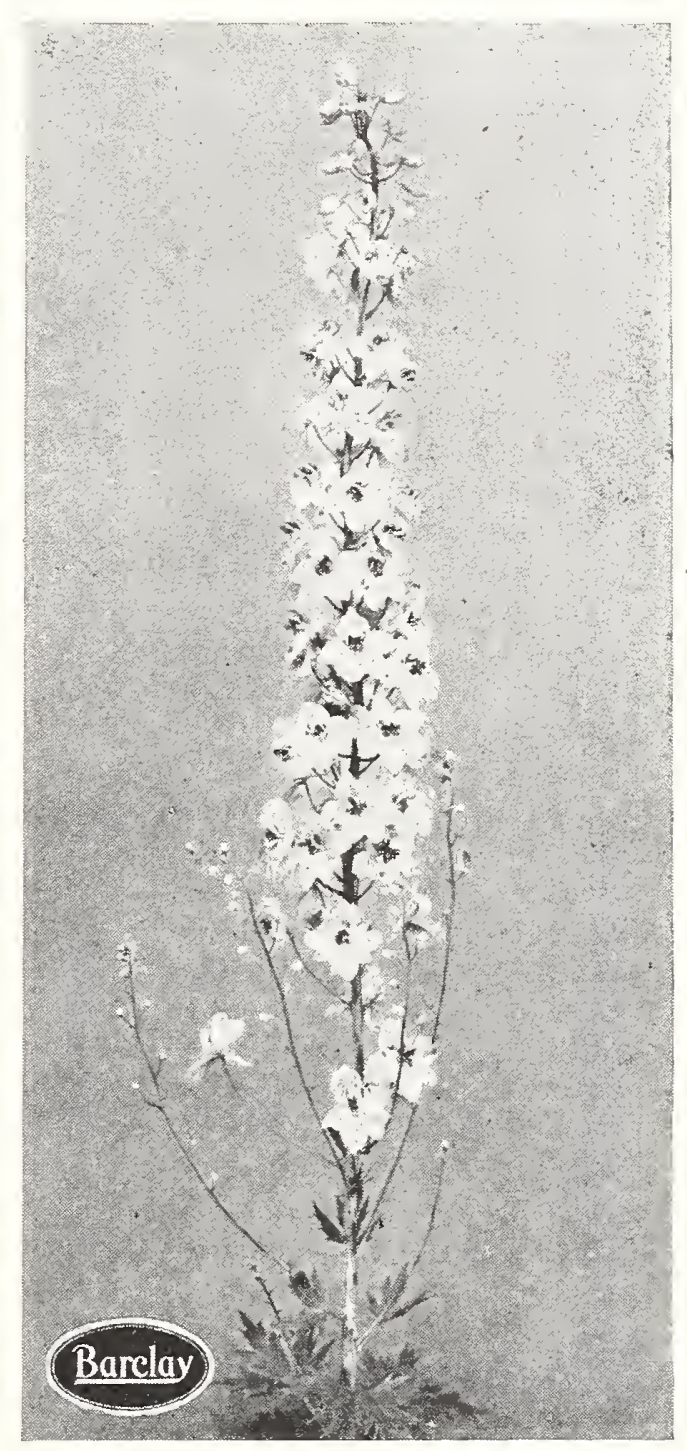

LIGHT BLUE AND MAUVE SEMI-DOUBLE BROWN EYE

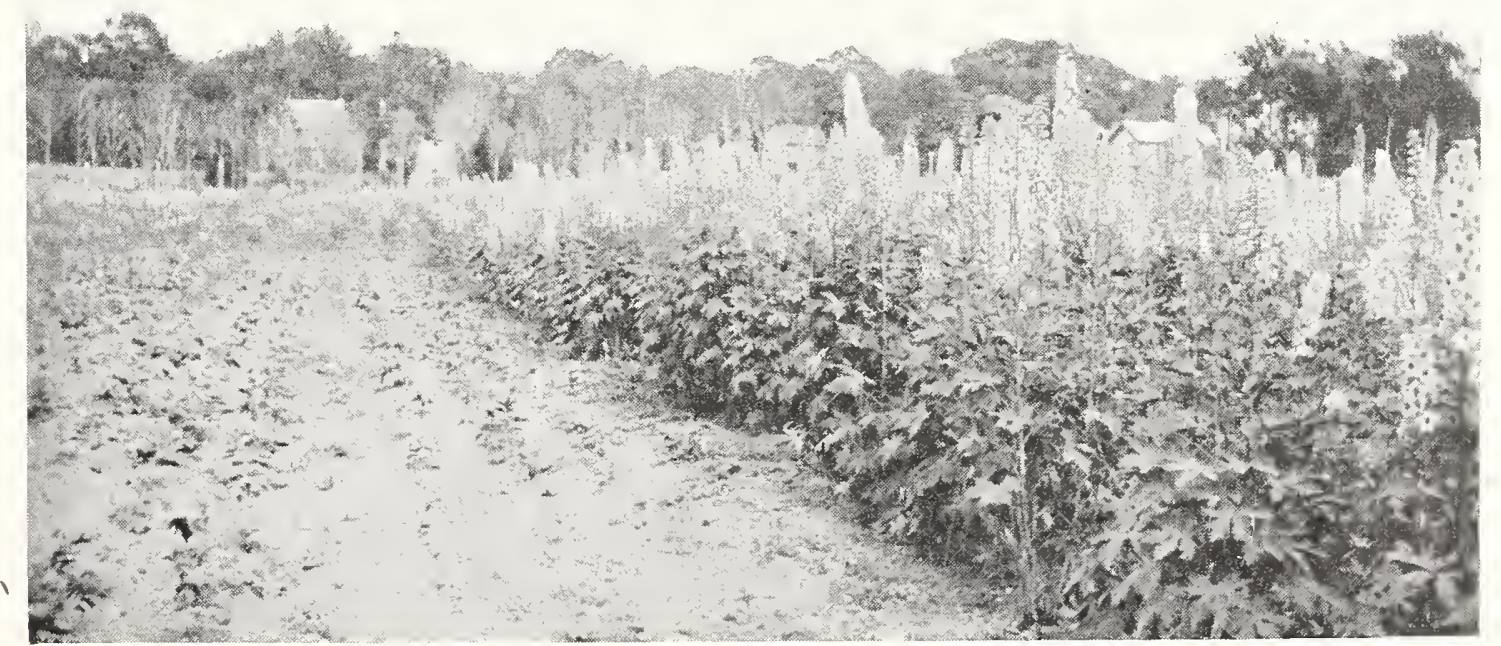

SEEDLINGS AND MATURED PLANTS IN THE "BARCLAY" FIELD 
JAMES FORBES BARCLAY, NEW ROCHELLE, N. Y.

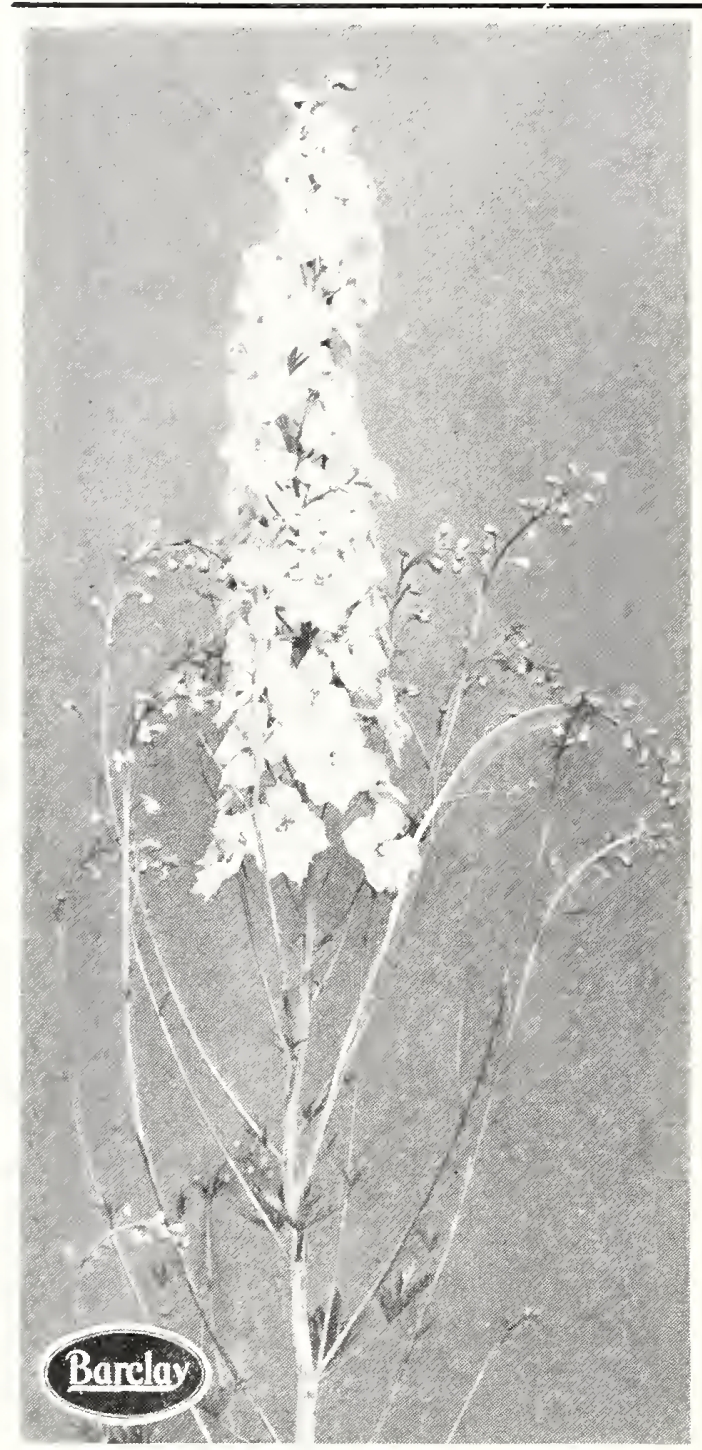

\section{Prices of Barclay}

\section{Hybrid Delphiniums}

PRICES: SUPER SELECTED SINGIE or DOUBIE FLOWERED, \$2.00, \$3.00, $\$ 5.00, \$ 7.50$ and $\$ 10.00$ each. A few very rare types at $\$ 15.00$ each.

All plants are field grown clumps, not divisions or rooted cuttings.

A very fine mixture of sincle or Double varieties for large plauting @ $\$ 11.00$ per dozen; $\$ 85.00$ per 100 . Write for further discount on larger quantities.

\section{TERMS}

$I$ respectfully request that cash, in the form of Money Order, Express Money order or cleck accompany all orders.

Packing is not charged for and all goods are delivered to the railroad or express company.

We use every care in the lifting and prompt packing and shipping of orders, and we will not be held responsible for delays, damage or other conditions, beyond our control, which may be detrimental to the contents, after de. livering in good order to the transportation company.

Discounts-5\% may be deducted on all orders amounting to 50 plants or more, and $10 \%$ on orders amounting to 100 plants or more.

GOOD SPIKE WITH WELI

DEVELOPED LATERALS

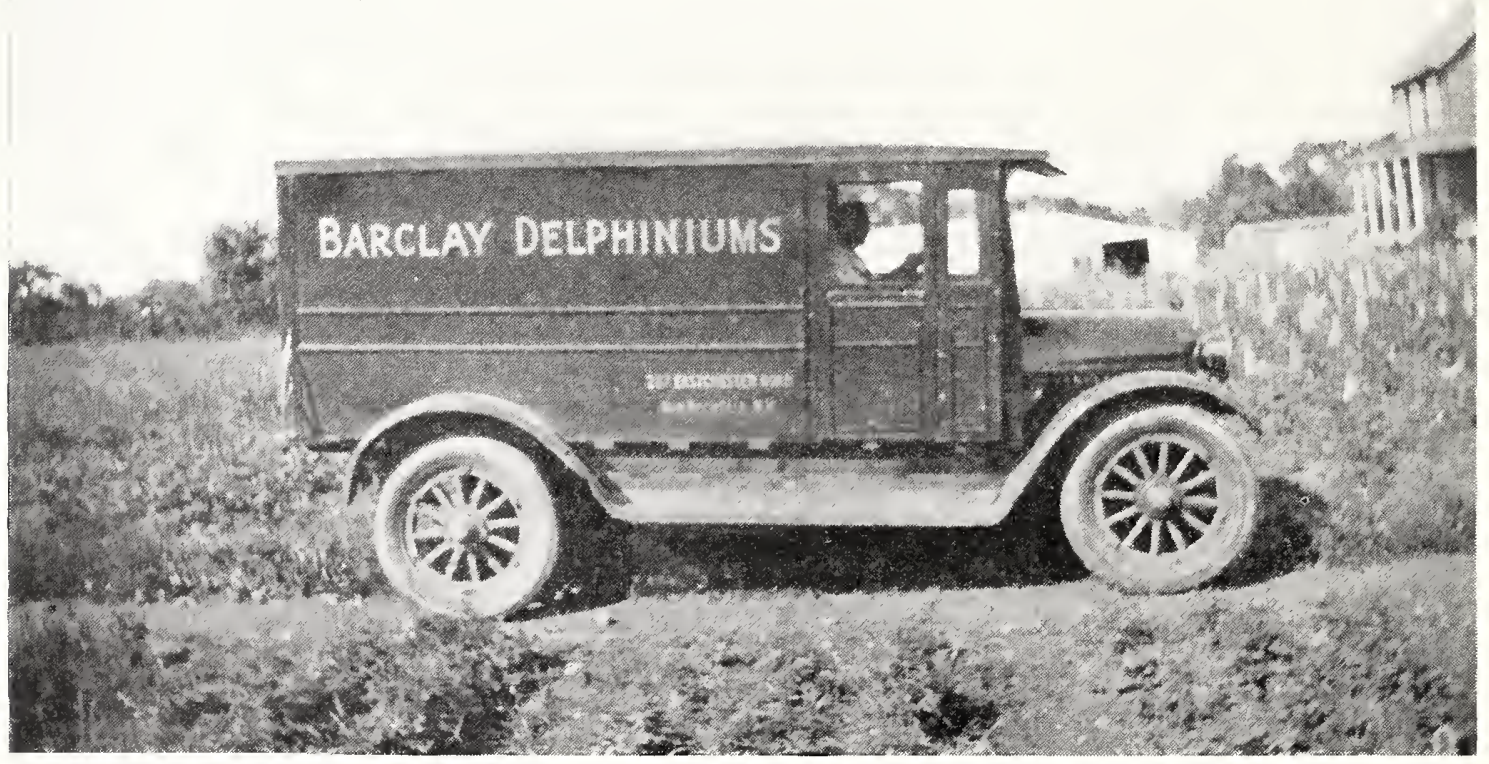

STYLISH TRANSPORTATION FACILITIES FOR “BARCLAY" DELPHINIUMS

Page Six 


\section{IMPORTANT NOTICE}

After exhaustive tests, we have decided to discontinue handling IMPORTED NAMED DELPHINIUMS listed on page 11 , as they have proved to be very unsatisfactory in this climate, and do not begin to compare with our own seedling stock, for health, strength, or vividness of coloring.

The list of Named varieties, on page 11, may be used as a guide to help you pick special types and colors, as we can supply near duplicates of most varietics.

\section{REVISED PRICES FOR 1929}

All two year Field Grown clumps selected and grown as follows:

"Barclay Super Hybrids" (the newest) Each \$5.00, \$7.50, and $\$ 10.00$.

Advancement Type and other Extra Choice ones $\$ 10.00$ to $\$ 15.00$ each.

"Extra Special" Picked Types per dozen $\$ 25.00$ and up. "Choice Mixed" \$11.00 per dozen; \$85:00 per 100 .

\section{UNFLOWERED SEEDLINGS}

On page 9 will be found a Photo of Seedlings planted out in field May 15th, these bloomed during August and September.

Many of these seedlings will produce plants that would sell, when in bloom, $\$ 5.00$ to $\$ 15.00$ each.

\section{PRICES}

Seedlings from seed saved from choice Named varieties in mixture, $\$ 3.00$ per dozen.

Seedlings from separate Named varieties, $\$ 5.00$ per dozen. Seedlings of NOVELTIES and OTHER. RARE varieties, $\$ 9.00$ per dozen. 


\section{GOOD DELPHINIUMS}

\section{Where and How to Grow Them}

The Delphinium has always been considered among the chief favorites of hardy flowers but the present day race of noble giants seems to have put them foremost of all. And there they stand today, towering, colorful columns that bring forth the highest praise and expressions of joyous wonderment from those who behold them.

The fine points in a wellbred Delphinium are many. First of all, color, then form and size of the individual flowers, and, of course, height, straightness and strength of stem.

The formation of the spike, in other words, the arrangement of the florets on the main stem is, perhaps, the greatest distinguishing point of the many types. Some favor the rather loose spike, where the florets do not touch; then, there is the compact, densely clothed spike, where the flowers not only touch, but overlap. What seems to be the ideal formation, however, is the spike of uniformly large florets that just touch one another, carried on short, sturdy, horizontal foot stalks to the main stem.

This arrangement is found in two types of spikes, the cylindrical and the tapering, both of which find about equal favor among judges. The famous Wrexham type has flower spikes mostly running to the tapering form.

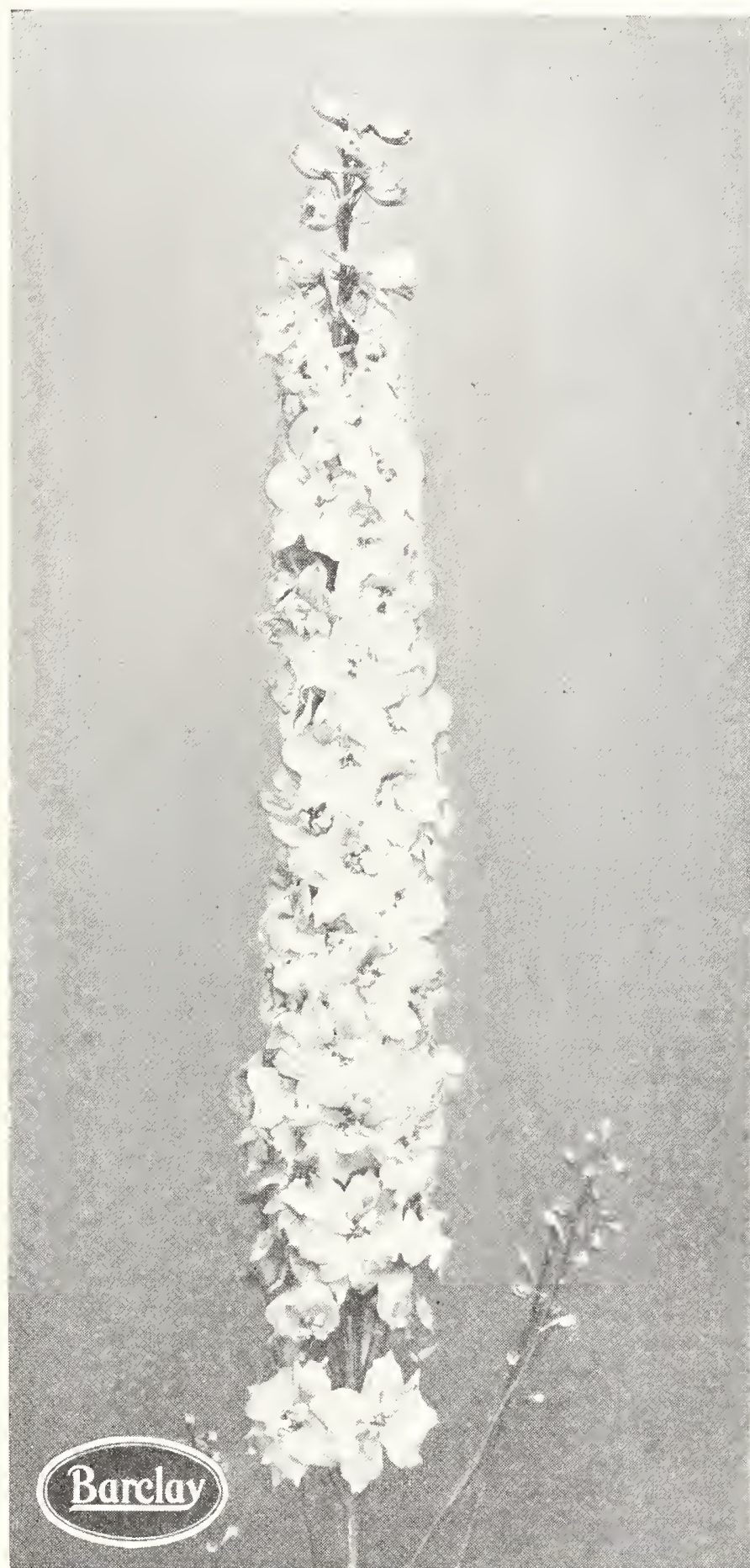

SPIKES SUCH AS TIIIS ARE NOTHING UNUSUAL IN "BARCLAY HYBRIDS"

\section{Barclay}




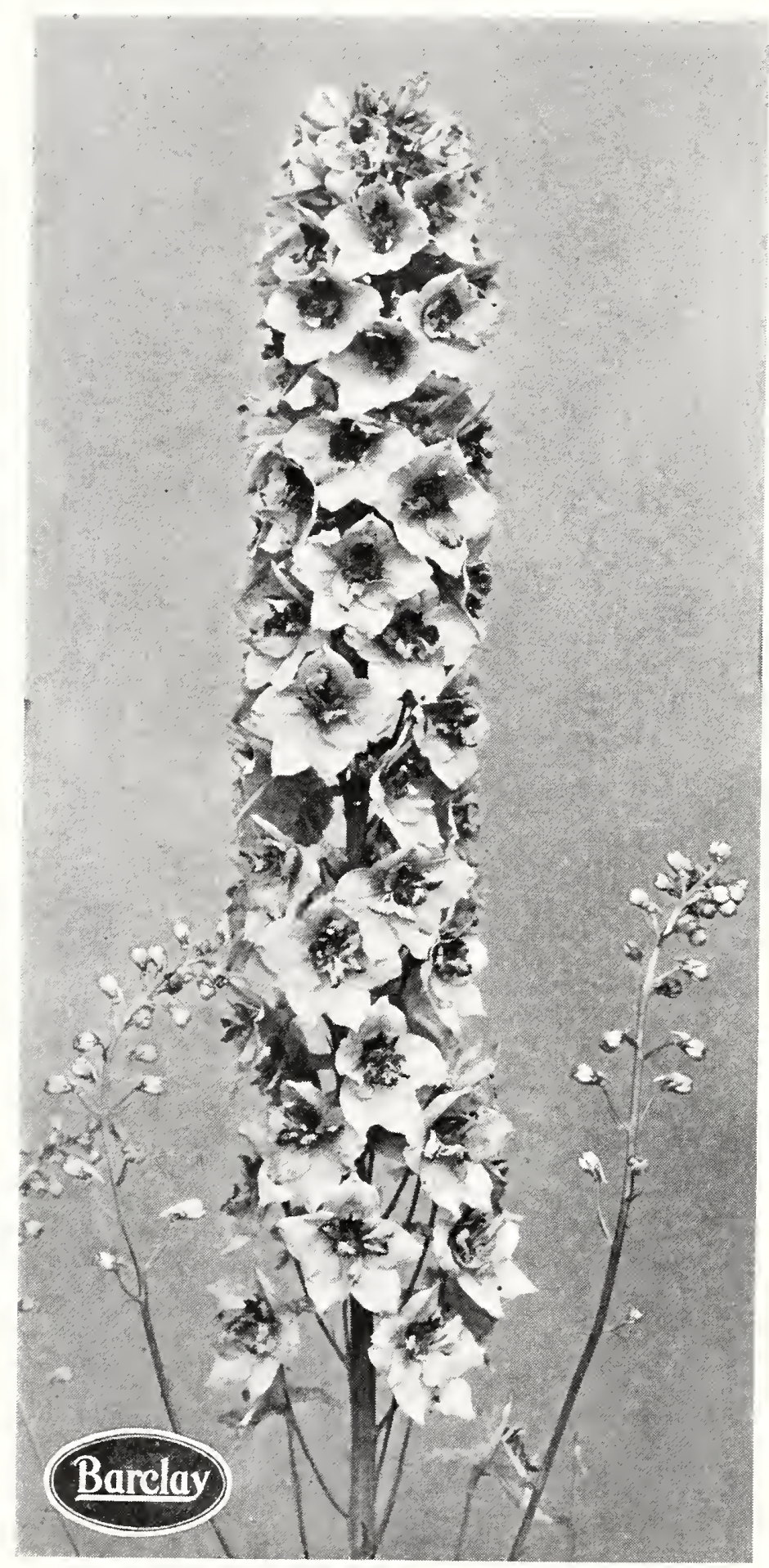

RICH GLOWING PURPLE WITH LARGE BLACK BEE

Delphiniums like a deeply dug, well drained rich fibrous loam. Manure should be discarded unless it is thoroughly rotten. Pulverized Sheep or Cattle Manure, is specially recommended, being clean, SAFE, free from weed seeds and fungus growths; this with the addition of bone meal, thoroughly mixed with the soil to a depth of one or two feet (the deeper you work your Delphinium bed the better results you will get). Slaked lime liberally applied and thoroughly incorporated within the soil is very beneficial.

'Should the soil be heavy (clay), sharp sand and Imported pulverized Peat are excellent to lighten soil; if very light and sandy use the peat liberally; this will conserve moisture.

If troubled with slugs, sprinkle slaked lime around the plants, rake in, and repeat dose as soon as lime cakes, efficient only while in dry powdery state. Cover crowns late in fall with sifted coal ashes to keep slugs away while plants are dormant.

Delphiniums will not succeed in shade, neither will the flowers withstand the heat of the hottest summer noonday sun, in Southern and Western States without bleaching. It would, therefore, seem that the most desirable locality is where light and air surround the plants and where a background of trees or tall shrubs, screen them from the mid-day sun. Here in New York and New England such protection is not required, as they will stand all the sun they can get.

Because Delphiniums are tall growing plants, they are usually put in the back row of the border with hollyhocks, phloxes, heleniums, etc. Of course, this is logPage Eight 
ical and correct to an extent, but much of their great beauty is thus lost by crowding. There is no reason why at intervals along the border, clumps cannot be placed prominently near the front, with a carpeting, as it were, of coreopsis, achillea, Iceland poppies or other plants of dwarfish habit and harmonizing colors. Such an arrangement emphasizes the beauty of the Delphinium foliage and flowers. There are two tall growing plants that really are good companions, because of their scanty or prostrate foliage, and those are Campanula Pyramidalis (blue and white) and the lovely Madonna Lily (Lilium Candidum). Planting may be done in spring or autumn.

Stimulants: In addition to the fertilizers applied at planting time, Delphiniums need "feeding" during the summer months, for the development of large spikes and the production of the second and third growths that appear at the base, after the first flower is cut.

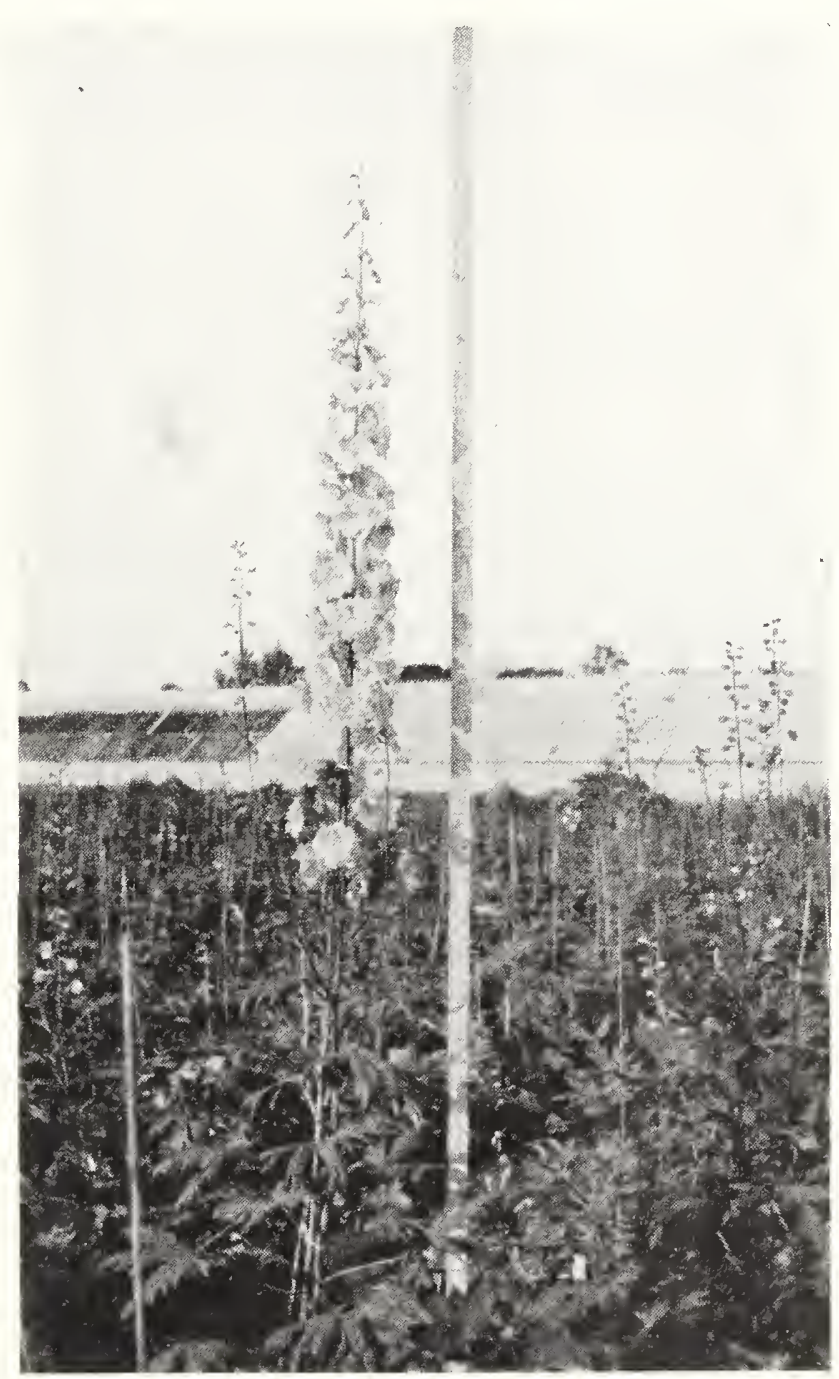

A BARCLAY HYBRID OF THE "WREXHAM" TYPE

Note how straight it grows, not staked. Flower spike 42 inches, $81 / 2$ inches at base.

After plants are established, the best results are to be obtained by liberal top feeding, withholding feed in spring, until flower spikes are well-formed-at which time liquid food may be given, also a copious supply of water, should the season be dry, they will repay you for the extra attention.

Bone meal, dried blood or Sheep Manure are as good as any I have tried, sprinkled lightly over the root area around the plants and watered in, the operation being repeated about every two weeks. It is advisable to lightly rake the fertilizer into the top soil before watering.

Delphiniums need the support of a stake, and I think a bamboo stake carefully tied to each stem to be the most approved method.

Cutting: Delphiniums should be cut when the spike is well developed. The terminal unopened buds will invariably open in water later. If the spike has only a few short laterals, cut away down to within 2 inches of the ground. If the laterals are long and promise to give good spikes of the second grade, cut the main spike just above the top lateral, then when the laterals have developed, cut the main stem down low as mentioned above. This low cutting is done to throw all the sap into the new growths, which appear at the surface and which give you a second crop of bloom. 
Never let your Delphiniums go to seed. Carefully pick the blooms off, just as soon as they wilt. There is quite an art, if not a secret, in breeding Delphiniums, and unless you understand how it's done, you will be disappointed. You can save the seed from the very finest named sorts, but unless they have been properly hybridized, the offspring will be very unlike the parents-a very sickly lot. Try it and see, but it is far better to cut your spikes and enjoy the second and third crops of bloom.

Diseases: Many complain that they cannot grow Delphiniums because of blight and black spot. I want to say right here that both of these can be both prevented and cured. There are several remedies on the market, but the best of all is QUA-SUL, a spraying material, that if used periodically through the year, from the time the plants are 6 inches high, you won't be bothered with either of these diseases. Price per qt. can $\$ 1.25$; gal., $\$ 4.00$. Full directions with each can.

All the Imported Named Varieties on Page 11, (with the exception of the first five) will be in bloom at the Gardens here July, 1927. Come and see them.

"Your Beautiful "Delphiniums" and "Lupines" are wonderful. I want to get several dozens of each, they are beyond anything I have ever seen.". F. G. (Lyme, Coun.)

"Mr. Rigby asked me to express my opinion vegarding your Delphiniums. Our Mr. Francis is quite an authority on Herbaceous Flowers and he agrees with me that you are to be congratulated upon the results you have achieved."

J. P. G. (New York)

"It is with much pleasure that I enclose herewith a 'Blue Ribbon' which was awarded to you for your beautiful Delphiniums. Our club members greatly admired them."

I. M. K. (Mt. Vernon Garden Club)

"Please enter my order for Delphiniums to the value of $\$ 100.00$., I an leaving the selection to you, knowing that you will do the best for me that you can."

C. D. A. (Pittsburgh, Pa.)

\section{Become a Member of the}

\section{AMERICAN DELPHINIUM SOCIETY}

All who are interested in Delphiniums, should join the American Delphinium Society. Membership application forms can be had from me, or from the Secretary, Amer. Delph. Soc., San Raphael, Cal. Membership fee, $\$ 1.00$ per year. The official publication of the Society, "Better Delphiniums," published twice yearly, is brimful of interesting information about modern Delphiniums, mailed to all subscribers for $\$ 1.00$ per year. 


\section{Named Wrexham Hybrids The Great "Advancement"}

Greatest and finest Delphinium creation ever produced. Even amazed the great English Delphinium connoisseurs; $6 \frac{1}{2}$ foot stem with a 4 -foot flower spike. Lovely bright blue, with pale mauve center and "Khaki eye."

Other "Wrexham" varieties that are really outstanding are as follows: "NORAH PHILLIPS" "ABOL," "KIA-ORA," "OLIVE GREAVES"; the above five novelties will be released fall, 1927, and will be seen in flower at my Test Gardens here summer of 1928 .

Also the following novelties "Integrity," "Great Strides," "Iose Marie" and "Ruffled Beauty"- the finest "Wrexham Hybrids" released this year-wonders in form and color.

\section{Other very choice named Wrexhams}

CAMBRIA. Long full spikes, semidouble flowers; heliotrope splashed with blue.

COQUExт. Fine blue and mauve. Single.

JOY BEILS. Distinct bell-shaped flowers of rich mauve.

MONARCH OF WALES. Deep blue, with reddish mauve center.
QUEEN MAUVE. Lovely pale mauve. Late.

PURPIE SPIENDOUR. Spiral spikes of amethyst and cornflower blue.

THE BISHOP. An outstanding wonder. Double violet blue; white eye VIOLET QUEEN. Deep violet, margined mauve: huge spike.

WINSOME. Tall spike; vivid rich blue.

\section{LARGE FLOWERED HYBRIDS FROM OTHER SOURCES}

BIUE BOY. Deep-blue, white eye; single.

BIUE PRINCESs. Sky blue, white eye; single.

BIUE QUEEN. Azure with black center; single.

CIARICE. Pink, changing to mauve; double.

COI. SIR WYNDHAM MURRAY. Bright blue, white center. Single.

CONSTANCE. Gentian blue, white eye; single.

FDWARD BROMET. Purplish blue, white eye, huge spike.

FAIRY QUEEN. Sky blue, black eye. Single.

F. W. SMITH. Gentian blue, white center.

GEO. COCHRANE. Rosy purple, white eye; semi-double.

GIORY. Mauve, shaded rose.

HARRY SMETHAM. Porcelain blue, semi-double.

IDA R. EIIIOTT. Cobalt blue; white eye.

JOSEF ISRAFIS. Royal blue and mauve; white eye.

J. PITTS. Sky bule and rose; black eye.

IADY HAIMMICK. Medium blue; white eye.

IADY BEATRIX STANXEY. Rich blue, white eye; single.

IAVANDA. Rosy lavender; white center.

IORD DERBY. Rosy mauve, white center.

IORD IANSDOWNE. Deep blue, white eye.

IORENZO de MEDICI. Blue shaded light pink; semi-double.

IIEUT. WARNEFORD, v. C. Deep velvety blue, semi-double.

MARJORIE FERGUSON. Sky blue and mauve; white eye.

MILIICENT BIACKMORE. Blue and mauve; black center.

MOERHEIMI. The first white Delphinium. 4-ft. Belladonna Type.
MONARCH OF AII. Violet and purple; brown eye.

MRS. T. G. BAKER. Clear bright blue single. $5 \mathrm{fr}$.

MRS. MARION CRAN. Pale azure blue; black eye.

MRS. F. IRAYE. Indigo and light purple.

MRS. COIIN MaIVER. Distinct shade of heliotrope.

MRS. SHIRIEY. Lilac mauve; white and sulphur eye.

MRS. TOWNIEY PARIER. Sky blue, white eye, very fine.

IMRS. A. J. WATSON. Deep mauve, black center, huge spike.

PANNONIA. Rich deep blue, white eye, well-shaped spike; 4 ft., 6 in.

PERFECTION. Grand light blue. $5 \mathrm{ft}$.

PURPIE KING. Deep blue and purple; black and gold eye.

PURPIE KING (Van Veen). Semidouble, beautiful bright rich purple - a remarkable color. Makes a good spike. $4 \mathrm{ft}, 6$ in.

QUEEN OF BATH. Lovely azure blue, single, conspicuous black centre, handsome foliage. $3 \mathrm{ft} .6 \mathrm{ln}$.

ROBERT COX. Rich blue and rosy lilac.

SIR DOUGIAS HAIG. Deep purple and blue; a giant.

STATUAIRE RUDE. Huge spike of pale heliotrope.

THE SHAH. Quite unique coloring, being a deep rosy-lavender self with dark eye. Large semi-double flowers are circular in form, and consist of several rows of petals. Spike extra long and finely proportioned. $5 \mathrm{ft}$. A.M.

TRIUMPH (Van Veen). Flowers of unique form resembling an immense hyacinth. Color soft blue, shade of plumbago capensis. $4 \mathrm{ft}$.

WIIIY O'BRIEN. Ultramarine and mauve.

W. T. WARE. Purplish blue; white eye. 


\section{Rare Types of well-known Perennials}

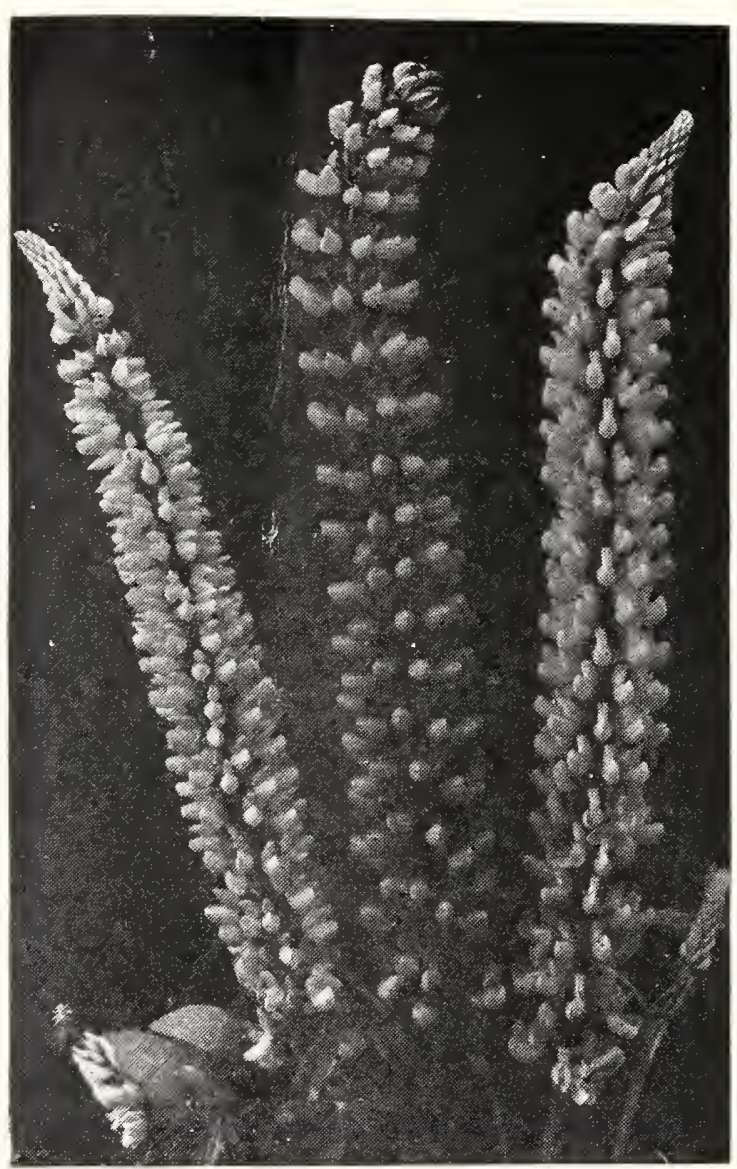

REGALE LUPINES

\section{REGAL LUPINES}

I also wish to call attention to my special line of Hybrid Lupines which make lovely companions to the Delphiniums, those listed are the cream of the worlass best--Harkness Gold Medal "REGAr. LUPINES" majestic in their splendor, their colors gleam like polished gold and burnisher copper, like leaping flames and molten metal, softer shades are like Apricots, Peaches and damsel's cheelis and the bicolors are like-well, thers is nothing on earth quite like them.

\section{Harkness "Regal" Hybrids}

Cleopatra; Fawn, yellow wings.

Dazzler; Reddish apricot, bright yellow wings.

Fortunata; Pale apricot, yellow wings. Gold Crest; Yellow, with blighter yellow wings.

John Harkness; Unique mahogany shade.

Joy; Apricot-pink, yellow wings.

Iady Greenall; Pure self-apricot, immense spikes.

Marjorie; Bronze yellow with darker shading.

May Robinson; Apricot and fawn.

Mascot; Rich glowing apricot, yellow wings.

winnie walker; Yellow, with bronze lustre.

winsome; Fawn, shaded yellow.

Strong, young plants, mixed, 50c each, $\$ 5.00$ per dozen.

SIDALCEA, STARK'S HYBRIDS (Novelty 1926.) This useful Hardy Plant is easily raised. I am offering a fine mixture, embracing colors, PALE PINE, SALIION PINK, ROSE AND CARMINE, down to CRIMSON. Both the height and form are variable, and it is quite possible to get some very good things. There are three distinct sections of flowering-Early June, mid-July to - dusust, lars August, and September. The Early section is splendid, to be used in conjunction with Delphiniums. The light habit of the plant, and the contrast of the colors, will make it valuable.

AQUIIEGIA. Selected long spurred Hybrids. A very choice strain, coming from a source acknowledged to be the finest in England.

GAILIARDIA. Choice exhibition Hybrids. Entirely distinct from the old kind, and from that offered elsewhere. A grand new improved strain. Enormous flowers and very stout habit. Many medals and certificates have been awarded to these hybrids.

PYRETHRUM ROSEUM. Exhibition strain. These comprise both single and double sorts in all the newest colors, and have attracted much attention at English shows. They will be much prized for cutting.

THALICTRUIM AQUIIEGIAEFOIIUM. (Feathered Columbine.) Whitish-yellow: vigorous; $3-4 \mathrm{ft}$. May-July.

THALICTRUM DIPTEROCARPUIM. Rosy-purple, 2-3 ft. June-August.

GEUIM MRS. BRADSHAW. Large brilliant searlet, splendid for cutting.

GEUIM IADY STRATHEDEN. Rich golden yellow, a counterpart in all other respects of the popular Mrs. Bradshaw.

Prices, all the above, extra fine clumps, selected @ 50c, 75c and $\$ 1.00$ each.

Special prices on large quantities of Perennials.

Page Twelve

\section{Barclay}

Hartland Adr. Service, Horticultural Writers and Printers, 154 Nassau Strect, New York 

